\title{
Laparoscopic management of impalpable testes in pediatric age group
}

\author{
Bassam K. Al Abbassi*, Muataz A. Al-ani** \\ *Department of Medicine, Pediatric Division, Nineveh College of Medicine, University of Mosul, \\ ** Pediatric surgery center, Al-Khanssa Teaching Hospital, Mosul.
}

(Ann. Coll. Med. Mosul 2012; 38 (2): 5-9).

Received: $24^{\text {th }}$ Nov. 2010; Accepted: $9^{\text {th }}$ Jul. 2012.

\section{ABSTRACT}

Aim of the study: The purposes of our study are to evaluate the role of laparoscopy in localizing impalpable testes and the management strategy for both unilateral and bilateral impalpable testes.

Patients and methods: Throughout the period between January 2005 to December 2008, 36 patients with impalpable testes were admitted to pediatric surgery centre at Al-Khanssa Teaching Hospital in Mosul, Laparoscopy done for them to assess and manage 42 impalpable testes.

In all patients $10 \mathrm{~mm}$ canula port was inserted in surpaumbilical position using an open technique, a single $5 \mathrm{~mm}$ port was occasionally required in contralateral iliac fosse to manipulate bowel and testes. A further port was used for laparoscopic clipping and division of the testicular vessels. These performed as the first part of the one or two stages Fowler- Stephen orchiopexy (high division of testicular vessels), and all patients has been followed for period of about two years.

Results: Twenty seven testes found to be positive, ten of them near the internal inguinal ring and nine in the iliac fossae, while two testes where found intra canalicular. Fifteen testes were absent with closed ring, 12 of them showed vas and vessels enter the internal ring (vanished testes), while three with no vas and vessels entering the ring (agenesis).

Assisted laparoscopic orchiopexy using sub dartous pouch was successfully done in 16 testes. Single stage Fowler-Stephen technique was adopted in four testes. Two stages for another two testes, in one patient, fixation done near upper scrotum which was then re fixed by second operation few months later.

Conclusion: Laparoscopy is a safe and reliable technique in diagnosing the presence or absence of impalpable testes, provides a valuable information about the associated anomalies and condition of the internal ring, it can direct the surgeon to chose the proper technique for orchiopexy, with no mortality and very low morbidity.

Keywords: Laparoscopy, impalpable testes, orchiopexy.

\section{الخلاصة}

هدف الدراسة: إن هدف دراستنا هو لبيان دور (تنظير البطن الجراحي) في تحديد (الخصى الغير مدكن إدر اكها باللمس) وتحليل

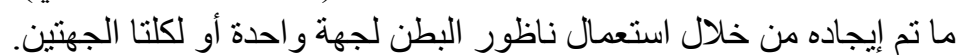

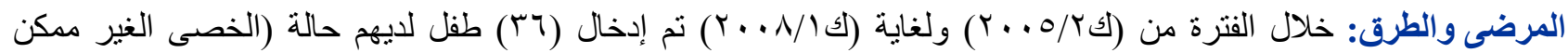

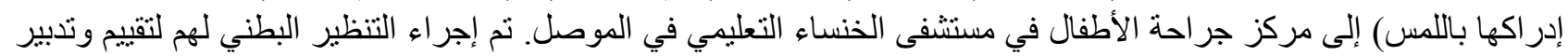

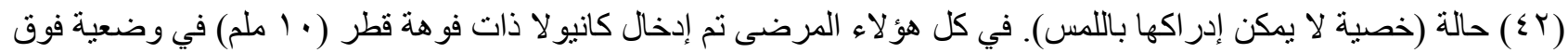

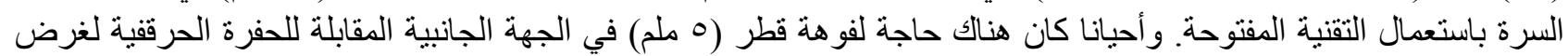

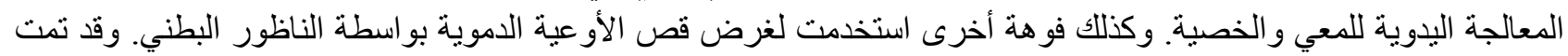
متابعة كل المرضى لفترة حو الي سنتين بعد العملية. 


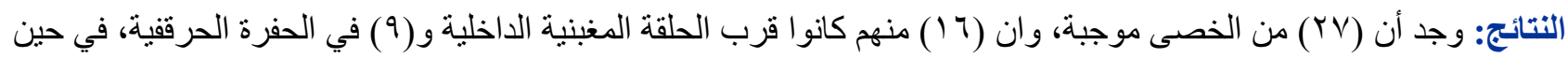

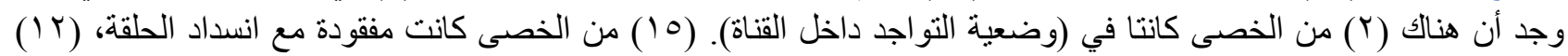

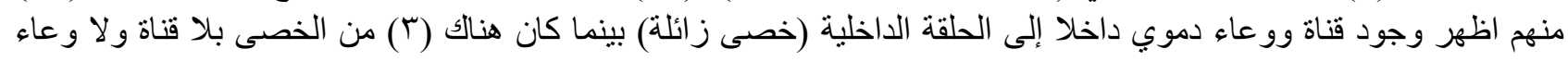

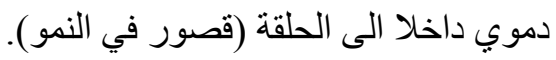

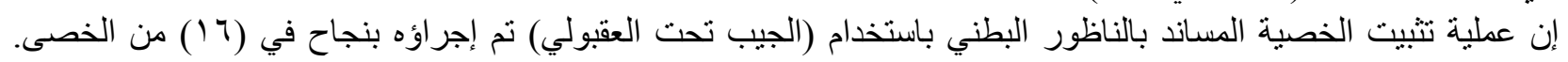

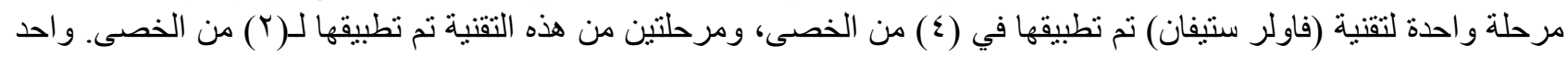

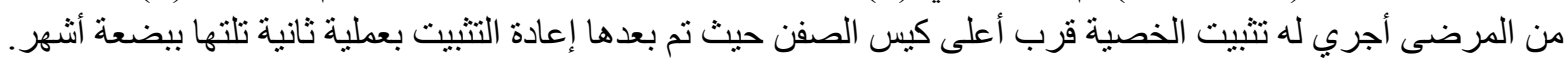

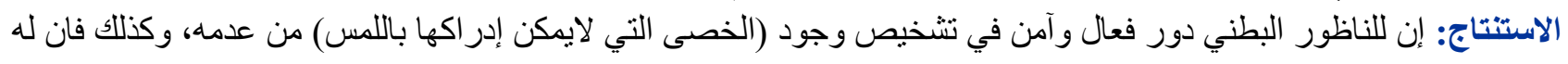

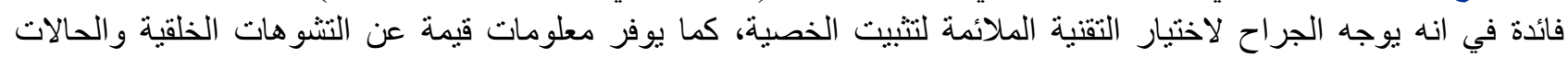
الأخرى المر افقة للحلقة الداخلية.

C ryptorchidism is a common finding in pediatric practice, it is encountered in $21 \%$ of preterm male infant ${ }^{(1,2)} 1.8-4 \%$ of all full term boys $^{(3)}$ and $0.8 \%$ of 1 year old boys ${ }^{(4,5)}$. The proportion of impalpable testis has been reported to vary from $8.3 \%$ to $20 \%$ of all cryptorchid boys. $^{(1,6-9)}$

A variety of imaging modalities have been used to detect the impalpable testis, these include ultrasound, computed tomography and magnetic resonance imaging, as well as more invasive procedures such as arteriography and venography. None are as sensitive as laparoscopy for accurate localization of the intra abdominal testes. ${ }^{(3,6,8-10)}$

Laparoscopy has been compared with the previous methods and has become the study of choice in most centers. ${ }^{(11,12)}$

To mobilize an intra abdominal testis, different techniques has been used, including two stage orchiopexy, ${ }^{(13)}$ micro vascular transfer of testes (microscopic anastamosis between main testicular vessels and inferior epigastric vessels) ${ }^{(2,14,15)}$ or Fowler-Stephen orchiopexy, one stage or two stage (high ligation or clipping of testicular vessels, followed by division $4-6$ months later). ${ }^{(2,15,16)}$

Diagnostic laparoscopy can be performed before groin exploration with little addition to the operating time and without complications, provided an open technique is used. ${ }^{(1)}$

Despite surgical treatments, unilateral and to a great extent, bilateral cryptochid patients have reduced fertility in adult life. ${ }^{(17,18)}$

The aims of our study are to evaluate the role of laparoscopy in our locality in localizing impalpable testes, analyze laparoscopic findings and define a management strategy for both unilateral and bilateral impalpable testis.

\section{PATIENTS AND METHODS}

Throughout the period between January 2005 to December 2008, 36 patients with impalpable testis were admitted to pediatric surgery centre in AlKhanssa Teaching Hospital in Mosul. Laparoscopy done for them to assess and manage 42 impalpable testes, their aged varied between 11 months to 12 years, six patients have bilateral impalpable testis. In two patients with bilateral impalpable testes the presenting symptom was ambiguous genitalia.

In all patients $10 \mathrm{~mm}$ canula port was inserted in supra umbilical position using an open technique, a single $5 \mathrm{~mm}$ port was occasionally required in contra lateral iliac fossa to manipulate bowel and testes, a further port was used for laparoscopic clipping and division of the testicular vessels. These performed as the first part of the one or two stage Fowler- Stephen orchiopexy, and all patients have been followed for period of about two years.

\section{RESULTS}

Twenty seven testes were found to be present, 16 of them were near to the internal inguinal ring, nine in the iliac fossae, while two testes were found in the intra canaliculae position. Fifteen testes were absent with closed ring, 12 of them showed vas and vessel entering the internal ring (vanished testes) while 3 with no vas and vessels entering the ring (agenesis) (Table 1).

The positive testes found to be of a good size in 13 testes, while 12 of them were small in size and 
the remaining two were very small and nearly atrophied.

Two patients with bilateral impalpable testes associated with ambiguous genitalia were found to have persistent Mullerian system syndrome, with small testicular tissue like structure, biopsied at laparoscopy and proved to be testicular tissue. They were lost for follow up.

Assisted laparoscopic orchiopexy using subdartous pouch were successfully done in 16 testes. Single stage Fowler-Stephen technique was adopted in four testes. Two stages for another two testes. In one patient groin fixation was done near upper scrotum which was then refixed by second operation few months later, (Table 2).

For majority of patients with testes near the ring, fixation successfully performed in the mid scrotum.

We followed our patients for about two years by assessing the size of the fixed testes in comparism to the other one, and in relation to patient age. It was of near normal growth size in 16 patients, five of them with Fowler- Stephen, while in five patients it was smaller in size and one patient with atrophied testis (Table 3).

Table 1. Laparoscopic finding.

\begin{tabular}{|c|c|c|c|}
\hline $\begin{array}{c}\text { Positive } \\
\text { testis }\end{array}$ & Vanished & Agenesis & Total \\
\hline 27 & 12 & 3 & 42 \\
\hline $67.5 \%$ & $30 \%$ & $2.5 \%$ & $100 \%$ \\
\hline
\end{tabular}

Table 2. Procedures used for fixations.

\begin{tabular}{|l|l|c|c|}
\hline \multicolumn{2}{|c|}{ Type of Procedures } & $\begin{array}{c}\text { No. of } \\
\text { Testis }\end{array}$ & $\%$ \\
\hline Assisted laparoscopic orchiopexy & 16 & 59.3 \\
\hline $\begin{array}{l}\text { Fowler-Stephen } \\
\text { orchiopexy }\end{array}$ & One stage & 4 & 22.2 \\
\cline { 2 - 4 } Two stages & 2 & 3.7 \\
\hline \multicolumn{2}{|l|}{ Tow- stages fixation } & 1 & 14.8 \\
\hline Other (Biopsy ) & 4 & 100 \\
\hline Total & 27 & \\
\hline
\end{tabular}

Table 3. Condition of testis in relation to procedures.

\begin{tabular}{|c|c|c|c|c|}
\hline $\begin{array}{c}\text { Condition of } \\
\text { the testis }\end{array}$ & Subdartous & $\begin{array}{c}\text { F. S } \\
\text { procedure }\end{array}$ & Total & $\%$ \\
\hline Good size & 12 & 5 & 17 & 74 \\
\hline Small size & 4 & 1 one stage & 5 & 21.8 \\
\hline Atrophy & 1 & 0 & 1 & 4.2 \\
\hline Total & 17 & 6 & 23 & 100 \\
\hline
\end{tabular}

\section{DISCUSSION}

Laparoscopy is a safe and reliable procedure that is highly accurate for diagnosis and treatment of numerous diseases. It has become established as the most reliable diagnostic modality for the management of impalpable testes. ${ }^{(9)}$ It provides clear demonstration for the anatomy, the location, and the size of the testes with their blood supply.

The key feature of laparoscopy for impalpable testes is the demonstration of the testicular vessels that implies the presence of the testis at some stage in development. ${ }^{(20)}$

Laparoscopy provides accurate localization of the testes in more than $95 \%$ and can be used for all age groups. ${ }^{(5)}$

According to Ashah $A \mathrm{~V},{ }^{(20)}$ the intra abdominal testis were classified according the laparoscopic findings into:

(1) Intra canalicular: if the vas and vessels were seen entering the internal ring.

(2) Low intra abdominal: if it is below the pelvic inlet and less than $3 \mathrm{~cm}$ from the internal ring.

(3) High intra abdominal: if it is above pelvic inlet and more than $3 \mathrm{~cm}$ from internal ring.

(4) Blind ending: vas and vessels suggest vanishing testis.

(5) Vas without vessels: suggest testicular agenesis.

Our findings were nearly similar to what described by Ashah $\mathrm{AV}$, but we add the condition of the ring whether it is opened or closed.

We classify our laparoscopic findings into the following:

1. Open inguinal ring: which includes:

a. The vas and vessel entering the ring (intra canalicular testes) (Figure 1).

b. Intra abdominal testis (Figure 2).

2. Closed inguinal ring: which includes:

a. The vas and vessels end blindly (vanished testes) (Figure 3).

b. No vas or blind end vas without vessels suggest testicular agenesis.

Patency of the ring at laparoscopy correlated strongly with presence of viable testes ${ }^{(21)}$.

On the other hand, in most cases open ring is not always associated with clinical evident hernia, until it is confirmed by clinical examination, or simple test intra operatively, otherwise we suggest the presence of patent process vaginalis. None of 
our patients had inguinal hernia that was evident clinically preoperatively.

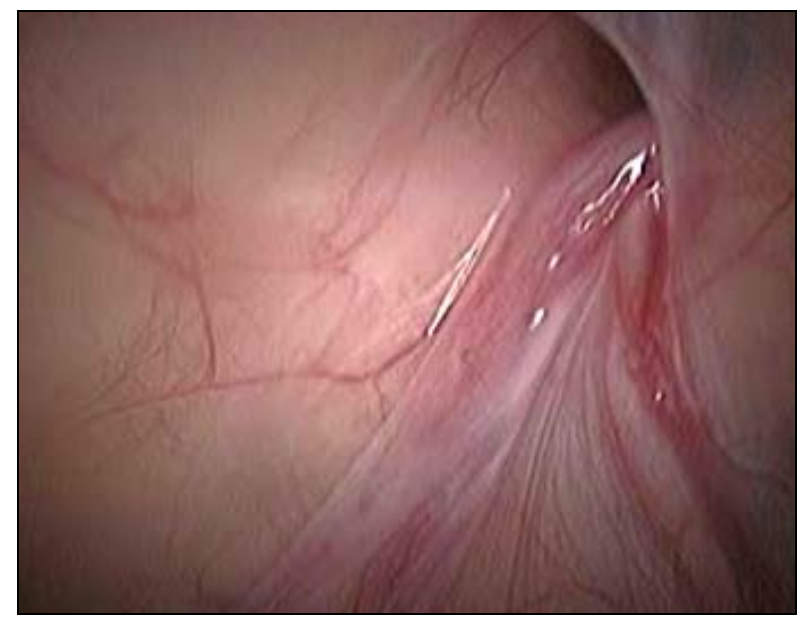

Figure 1. Vas and vessel entering the internal ring.

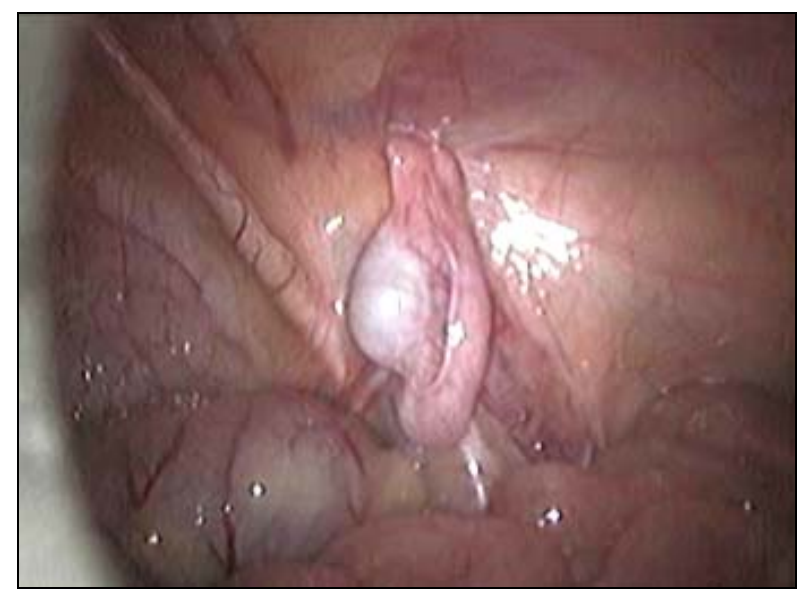

Figure 2. Intra abdominal testis.

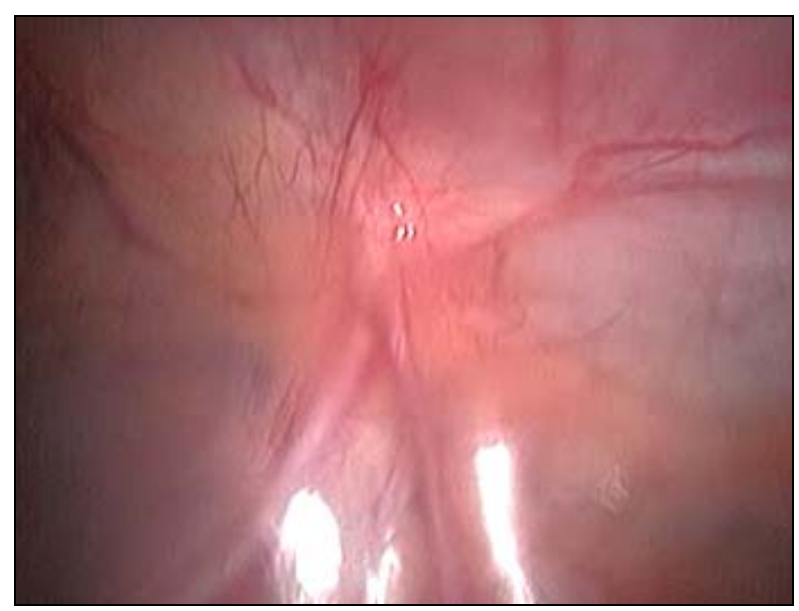

Figure 3. Vas and vessel end blindly. (vanished testis).
When a testis is seen in the abdomen, assessment made depending upon its distance from the pelvic brim and internal ring, or using the cord mobility as a guide to cord length, here the testes is displaced by stretching it toward the opposite internal ring (stretching maneuver) if positive, it mandate orchiopexy otherwise a stage approach should be considered. ${ }^{(22)}$ We depend on this maneuver for our decision making to chose for one stage or two stages orchiopexy. In addition our decision to chose technique for the high testes (seven testes in the right ileac fossae) depend on temporary clamping of the testicular vessels and watching the condition of the testis with wide dissection around the testis, this provide about $30 \%$ incidence of atrophy. ${ }^{(23,24)}$

In tow testes signs of ischemia started shortly, we prefer to use tow stage technique with high clamping of testicular vessels to be followed 6-9 months later by Fowler Stephen assisted laparoscopic orchiopexy. In four testes the good color of the testes encouraged us to do one stage fowler Stephen technique, with high division of the testicular vessels and careful dissection away, and around the vessels and testes, followed by successful fixation in the mid scrotum without tension. One testis showed good mobility and fixed in upper scrotum without tension or the need of Stephen fowler technique.

Our criteria for the diagnosis of vanishing testis are to see the vas and vessels ending blindly at or above internal ring. ${ }^{(25)}$

We recommend additional inguinal exploration (although it is not considered mandatory by others ${ }^{(26)}$ ) to view the potential risk for testicular malignancy if residual testicular tissue present through excision and histopathological study.

We followed our patients for a period of about two years by assessing the size of the testis in comparison to the other normal testes and in relation to the age.

Although one stage Stephen fowler technique with high ligation of the vessels associated with $30 \%$ incidence of atrophy in some series, ${ }^{(23,24)}$ none of our patients with one stage Fowler Stephen technique showed complete atrophy after one year. On the other hand, four testes with usual laparoscopic assisted orchiopexy get smaller few months after, and one testis with one stage Fowler Stephen giving $21.8 \%$ risk of small size testes 
which may be attributed to vascular compromise at time of surgery. This finding suggests that one stage Stephen fowler laparoscopic orchiopexy encouraged to be used in high testis, but large series study is needed to standardize this technique as a first choice. One patient showed complete atrophy (4.2\%) and it might be secondary to pull under tension.

\section{CONCLUSION}

Laparoscopy has a safe, reliable and accurate role in management of impalpable testes, and it is role in the management of impalpable testes is vital through assisted orchiopexy. It also directed the surgeon to choose the proper technique for orchiopexy; provide valuable information about the associated anomalies and condition of the internal ring.

One stage assisted laparoscopic orchiopexy is still the standard technique for testes near the ring. Single stage Fowler Stephen laparoscopic orchiopexy can be used with good results and two stages Fowler Stephen can be used successfully in managing of high intra abdominal testes.

\section{REFERENCES}

1. Baillie CT, Fearns G, Kitteringham L, et al. Management of the impalpable testis: The role of laparoscopy: Arch Dis. child 1998; 79:419 - 422.

2. John M. Huston Orchidopexy in lewis spitz: Arnold G. Coran eds Rob and smiths operative pediatric surgery. Fifth ed. Chapman \& Hall medical; 1995.p.717-725.

3. Froeling FM, Sorber MJ, dela Rossette JJ, et al. The non palpable testis and the changing role of laparoscopy. Urology 1994; 43: 222-7.

4. Scoter C G. The descent of the testis. Arch Dis child 1964;39:603- 609.

5. Poenaru D, Homs VL, peloquin $F$, et al. Laparoscopic management of impalpable abdominal testis. Urology 1993; 42:574-8.

6. Elgohary M.A. The role of laparoscopy in the management of impalpable testes. Pediatr. surg. int.1997; 12:463-465.

7. Zerella JT, Mc Gill LC. Survival of non palpable undescened testicles after orchidopexy. J pediatr. Surg. 1993; 28: 251-53.

8. Heiss KF, Shandling B. Laparoscopy for the impalpable testis: experience with 53 testes. J pediatr surg 1992; 27:175-8.

9. Elgohary M.A. Role of laparoscopy in the management of impalpable testes: J Indian associ pediatr surg. 2006; 11(4): 207-210.
10. Tennenbaum SY, lerner SE, MC Aleer IM, et al. Preoperative laparoscopic localization of the non palpable testis: a critical analysis of a 10 years experience. J Urol 1994; 151:732-40.

11. Boddy SAM, Corkery JJ, Gornall P. The place of laparoscopy in the management of the impalpable testis. Br J surg 1985; 72: 918-919.

12. Fahlen kamp D, Raatz D, Schonberger B. Diagnostic laparascopy in management of cryptorchidism. Urologe Arch 1992;31: 328-322.

13. Steinhardt GF, Kroovand RL, Perlmutter AD. Orchiopexy: planned 2 stages technique. J Urol 1985; 133:433-434.

14. Wacksman J, Dinner M, Handler M. Results of testicular auto transplantation using the microvascular technique experience with 8 intra abdominal testis. J. Urol 1982; 128: 1319-1321.

15. Boddy SA, Gardon AC, Thomas DFM, Browning FSC. Experience with the Fowler-Stephens and microvascular procedure in the management of intra abdominal testis. Br J Urol 1991; 68:199- 202.

16. Fowler R JR, Stephens FD. The role of testicular vascular anatomy in the salvage of high undescended testes. Aust NZ J surg 1959;29:92106.

17. Kogan SJ, Fertility in cryptorchidism. An over view in 1987. Eur J pediatr 1987; 146 (Suppl 2): 21-4.

18. Chilvers C, Dudley $\mathrm{N}$ E, Cough $\mathrm{M} \mathrm{H}$, et al. Undescended testis: the effect of treatment of subsequent risk of subfertility and malignancy. J pediatr surg 1986; 21: 691-6.

19. Lowe DH, Brock WA, and Kaplan GW. Laparoscopy for localization of nonpalpable testes. J Urol 1984; 131:728-792.

20. Ashah AV. The impalpable testis -peeping through the key hole. J Indian assoc. pediatr. surg. 2003; 8: $208-212$.

21. Elder JS. Laparoscopy for impalpable testes: significance of patent processus. vaginalis. J Urol 1994;152: 776 - 778.

22. Banieg hbal B, Davies M. Laparoscopic evaluation of testicular mobility as a guide to management of intra abdominal testes. World J Urol 2003;20(6): 343-5.

23. Snyder H M III, Duckett JW. Orchidopexy with division of spermatic vessels: review of ten year experience. J Urol 1984;131:126 A.

24. Clat worthy HW Jr, Hollabaugh RS, Grosfeld JL. The "long loop vas" orchiopexy for the high undecesended testis. Am surg. 1972; 38:69-73.

25. Stephen ET, Lawrence JM. The vanishing testis syndrome: indication for conservative therapy. J Urol 1986;2:758-4.

26. Schleef J, Von Bismarch S, Burmucic K, et al. Groin exploration for non palpable testis: laparoscopic approach. J pediatr surg 2002; 37:1552-1555. 